\title{
El-Fayah
}

JURNAL BIOLOGI

Journal Homepage: http://ejournal.uin-malang.ac.id/index.php/bio/index

e-ISSN: 2460-7207, p-ISSN: 2086-0064

\section{Salicylic Acid from Gandapura Oil as an Inhibitor of Ethylene Biosynthesis in Malus sylvestris L. Mill}

\section{Dodyk Pranowo, Desiree Rain Rahima, Imam Santoso}

Department of Agroindustrial Technology, Faculty of Agricultural Technology, Brawijaya University Malang. J. Veteran Malang, Indonesia

"Corresponding author

Email: dodykpranowoo@ub.ac.id

DOI: 10.18860/elha.v8i1.11322

\begin{tabular}{l} 
A r t i c l e I n f o \\
\hline Article history: \\
Received 19 march 2020 \\
Received in revised form \\
02 july 2020 \\
Accepted 27 august 2020 \\
\hline Key Word: \\
Apple, \\
salicylic acid, \\
ethylene biosynthesis inhibitor, \\
growth regulator
\end{tabular}

\section{INTRODUCTION}

Apple plants are one of the plants that are suitable for planting in highland areas with low temperatures. One of the locations that has become the center for apple plants in Indonesia is Batu City, East Java. One type of apple plant that is cultivated in Batu City is the Anna apple. Anna's apples contain water and predominantly vitamin $\mathrm{C}$, so this apple has a

\begin{abstract}
Local apple production, especially Anna's apples, continues to decline. One of the Causes of the decline in local apple production is due to the disproportionate use of chemicals, which causes ethylene production in plants to increase. The purpose of this study was to examine the effect of salicylic acid on reducing levels of ethylene concentrations in Anna apple plants. This study used a completely randomized design (CRD) with a single factor, namely the treatment of various salicylic acid concentrations (25 ppm, 50 ppm, 100 ppm, 200 ppm). The results showed that salicylic acid was able to reduce the value of ethylene concentration in plants. Provision of salicylic acid concentrations starting at $25 \mathrm{ppm}$ was able to inhibit ethylene biosynthesis by more than $90 \%$. The best results were shown in samples treated with 200 ppm salicylic acid concentration. By using salicylic acid alternatives, farmers are able to save around $R p 3,040,400$ in costs in one harvest period. The percentage of costs for salicylic acid in one harvest period is $3.39 \%$ of the total production costs, while the cost of the import promoter is $7.92 \%$ of the total production costs.
\end{abstract}

strong aroma with a fairly sour taste. Anna's apples are very crunchy, soft and have a lot of water content. The skin of Anna's apple is reddish and the fruit has an oval shape with an inward indented base and a shallow grooved tip(Yulianti, et al., 2007). Anna's seven-year-old apple tree can produce between $15-20 \mathrm{~kg}$ of fruit per tree per year(Gardjito et al., 2015). 
Apple (Malus sylvestris L.) is in great demand because it contains several nutrients such as fiber, minerals, vitamins, and antioxidants (Ferretti et al., 2014). The high market demand makes local apples and imported apples have to compete in the market. According to the Central Bureau of Statistics for Batu City (2017), in recent years the production of Batu apples has continued to decline, for example, such as 2013 (838.91 tons), 2014 (708.43 tons), down to 650.02 tons (2015), and fell again in 2016 (542.11 tons). The declining condition of local apple production has made imported apples more abundant in the market to meet consumer needs. The decline in apple production rates can occur due to various things, including agro-climatic factors and non-climatic factors in Batu City which are no longer conducive to apple growth. According to (Ruminta, 2015), nonclimatic factors such as old apple plant age, less intensive apple cultivation, land conversion for apple plants which causes a reduction in the number of apple trees planted, and decreasing apple prices have more impact on decreasing apple production in Batu. Poor. Another factor that can trigger the decline in apple production is the use of inappropriate or excessive amounts of chemicals in plants. According to (Würschum et al., 2015), chemicals that accumulate in the soil and in apple plants with excess concentrations can trigger an increase in ethylene production in plants. Excess ethylene production will result in leaf shedding, flowering failure, difficulty forming new branches, stems shrinking, and root damage. Non-climatic factors such as old apple trees, less intensive apple cultivation, land conversion for apple plants which causes a reduction in the number of apple trees planted, and decreasing price of apples have more influence on the decline in apple production in Batu Malang. Another factor that can trigger the decline in apple production is the use of inappropriate or excessive amounts of chemicals in plants. According to (Würschum et al., 2015), chemicals that accumulate in the soil and in apple plants with excess concentrations can trigger an increase in ethylene production in plants. Excess ethylene production will result in leaf shedding, flowering failure, difficulty forming new branches, stems shrinking, and root damage. Non-climatic factors such as old apple trees, less intensive apple cultivation, land conversion for apple plants which causes a reduction in the number of apple trees planted, and decreasing price of apples have more influence on the decline in apple production in Batu Malang. Another factor that can trigger the decline in apple production is the use of inappropriate or excessive. According to (Würschum et al., 2015), chemicals that accumulate in the soil and in apple plants with excess concentrations can trigger an increase in ethylene production in plants. Excess ethylene production will result in leaf shedding, flowering failure, difficulty forming new branches, stems shrinking, and root damage.

To overcome this problem of high ethylene production, materials are needed that are safer and more economical than products commonly used by farmers (import promoters). One of the alternative materials to overcome this problem is salicylic acid. The salicylic acid to be used is the result of synthesis from gandapura oil or wintergreen oil which has a main component of methyl salicylate reaching 93-98\%. Gandapura oil itself is one of the natural ingredients that are abundant in Indonesia. Salicylic acid has been shown to significantly inhibit ethylene production in horticultural crops so that it can delay the ripening process of climatic fruit (Asghari \& Aghdam, 2010). According to Leslie \& Romani (1988) who conducted research on pear cells (Pyrus communis L.), salicylic acid can inhibit ethylene biosynthesis up to $94 \%$ inhibition. The use of salicylic acid is also able to reduce the use of chemicals in apple plants. This study aims to test the administration of salicylic acid to reduce levels of ethylene concentration in Anna apple plants. 


\section{MATERIALS AND METHODS}

Materials used in this study were: salicylic acid obtained from synthesis of gandapura oil, one year old apple plant, Ethrel (acid-2chloroethyl phosphornate), aquades, n-hexane (pa), $\mathrm{MgSO}_{4}$ anhydrous (pa), digital scales, measuring cups, spray bottles, crop scissors, knife label paper, glassware, mortar, Whatman filter paper and Gas Chromatograph-Mass Spectrometry (GC-MS).

\section{a) Research design}

This study was prepared using a completely randomized design (CRD) with a single factor, namely the concentration of salicylic acid. A total of 18 treatments consisted of six different concentrations of salicylic acid with each treatment repeated three times.

Table 1. Treatment of Salicylic Acid Application on Apple Plants

\begin{tabular}{|c|c|c|}
\hline \multirow[b]{2}{*}{ Pot Code } & \multicolumn{2}{|l|}{ Treatment } \\
\hline & $\begin{array}{l}\text { Salicylic Acid } \\
\text { Concentration } \\
(\mathrm{ppm})\end{array}$ & $\begin{array}{l}\text { Giving } \\
\text { Ethylene } \\
\text { (ppm) }\end{array}$ \\
\hline Control & 0 & 0 \\
\hline AS-0 & 0 & 12 \\
\hline AS-25 & 25 & 12 \\
\hline AS-50 & 50 & 12 \\
\hline AS-100 & 100 & 12 \\
\hline AS-200 & 200 & 12 \\
\hline
\end{tabular}

The first stage of this research is the preparation of one year old Anna apple plant. There were 18 apple trees with uniform diameter and stem height and then sprayed with $12 \mathrm{ppm}$ ethylene. Spraying is carried out using a farmer method approach, namely by spraying a solution that has been mixed with distilled water. A week after ethylene spraying, the apple plant was sprinkled with the leaves and stem tips. The next step is to prepare salicylic acid according to the concentration to be used. For a salicylic acid concentration of 25 ppm, 25 grams of salicylic acid and $1 \mathrm{~L}$ of distilled water are used to make the solution, then the same thing is done to make each of the required concentrations. Five days after the vandalism, the shoots began to grow and began to be sprayed with salicylic acid according to each treatment ( $25 \mathrm{ppm}, 50 \mathrm{ppm}$, 100 ppm, and 200 ppm). Spraying of salicylic acid is carried out twice, namely when the shoots begin to grow after being diagnosed and when the plants begin to flower. Plant development was observed for 35 days with descriptive observations which included a comparison of leaf and flower shedding and a comparison of the level of formation and development of fruit. Ethylene concentration was obtained from 10 grams of sample (fruit or leaf shoots) which was then extracted using $n$ hexane solution. The extract was then filtered and dried over anhydrous MgSO4. The final step is to inject the extract into the Gas Chromatograph-Mass Spectrometer (GCMS).

\section{b) Data Analysis}

Data analysis was performed using Analysis of Variance (ANOVA) followed by the DMRT (Duncan's Multiple Range Test) at a test level of $5 \%$ to determine the significant difference between treatments.

\section{RESULTS}

\section{a) Plant Development}

Anna apple plants were treated with ethylene at the beginning of the study to increase the concentration of ethylene in the plant, so that it could be observed the effect of salicylic acid concentration in suppressing the ethylene concentration in apple plants. Ethylene concentration had a major effect on the development of Anna apple plants.

Table 2. The Effect of Salicylic Acid on the Development of Apple Plants

\begin{tabular}{llll}
\hline Treatment & Leaf & Flower & Fruit \\
\hline Control & There is & There is & There is no \\
\hline AS-0 & There is & There is & There is no \\
\hline AS-25 & There is & There is & There is \\
\hline AS-50 & There is & There is & There is \\
\hline AS-100 & There is & There is & There is \\
\hline AS-200 & There is & There is & There is \\
\hline
\end{tabular}

In Table 2 it can be seen how the development of each plant that has been given 
different treatments. Fertilization does not occur in plants that are not given salicylic acid. This shows that salicylic acid can trigger fruit formation in apple plants. (Djamhari, 2010) reports that the formation of phytohormones can be accelerated by applying exogenous ZPT in plants, so that this can encourage a biochemical activity in these plants. In this study, exogenous ZPT in the form of salicylic acid can suppress ethylene production and increase auxin which is more needed in the development process of apple plants. According to (Leslie \& Romani, 1986), This can occur because salicylic acid provides a blocking action against the active side of the ACC oxidase enzyme which plays a role in the conversion of 1-aminosyclopropane-1carboxylic acid compounds to ethylene. In the actual process, if salicylic acid is not added, the ACC oxidase enzyme will produce ethylene from the synthesis. With the addition of salicylic acid, the active side of the ACC oxidase enzyme is blocked and 1-aminosyclopropane-1carboxylic acid cannot synthesize to produce ethylene in plants.

\section{b) Ethylene Concentration}

Table 3. Effect of Salicylic Acid Concentration on Average Ethylene Concentrations in Apples

\begin{tabular}{cc}
\hline $\begin{array}{c}\text { Ethylene } \\
\text { Concentration (ppm) }\end{array}$ & $\begin{array}{c}\text { Average Ethylene } \\
\text { Concentration (ppm) }\end{array}$ \\
\hline Control & $10.23 \mathrm{a}$ \\
\hline 0 & $15.50 \mathrm{~b}$ \\
\hline 25 & $0.96 \mathrm{c}$ \\
\hline 50 & $0.92 \mathrm{C}$ \\
\hline 100 & $0.36 \mathrm{c}$ \\
\hline 200 & $0.28 \mathrm{~d}$ \\
\hline
\end{tabular}

* Values followed by the same letter show results that are not significantly different in the Duncan test at the level of $\alpha=5 \%$

The ethylene concentration value in apple plants was obtained from the measurement of ethylene from the extraction of plant shoots or apples on a GCMS machine. In Table 3, it can be seen that the ethylene concentration value of each apple plant that has been given different treatments. There is a significant difference in the value of ethylene concentrations between plants given salicylic acid and those not given salicylic acid.

Table 3 also shows that giving different salicylic acid concentrations results in different mean values of ethylene concentrations in apple plants. The $25 \mathrm{ppm}$ salicylic acid concentration has been able to be used to inhibit ethylene performance, especially in the shedding of flowers and fruit, which have been the cause of losses in apple farming. The concentration of salicylic acid $25 \mathrm{ppm}$ with salicylic acid $50 \mathrm{ppm}$ was not significantly different but had a significant effect on other treatments. The administration of salicylic acid 100 ppm with 200 ppm was also not significantly different but significantly different from other treatments. The existence of a significant difference between the provision of salicylic acid concentrations of 50 ppm and 100 ppm makes the $100 \mathrm{ppm}$ to $200 \mathrm{ppm}$ salicylic acid treatment more applicable in the handling of apple plants during the flowering and fertilization period to obtain maximum flowers and apples, as evidenced by more fruit yields. at this concentration. According to (Moore, 1979), giving a concentration of growth regulators will produce different effects for each type of plant, even between varieties within one species. One of the factors that affect the effectiveness of giving growth regulators to plants is the concentration of the substance given, different concentrations will cause different activities.

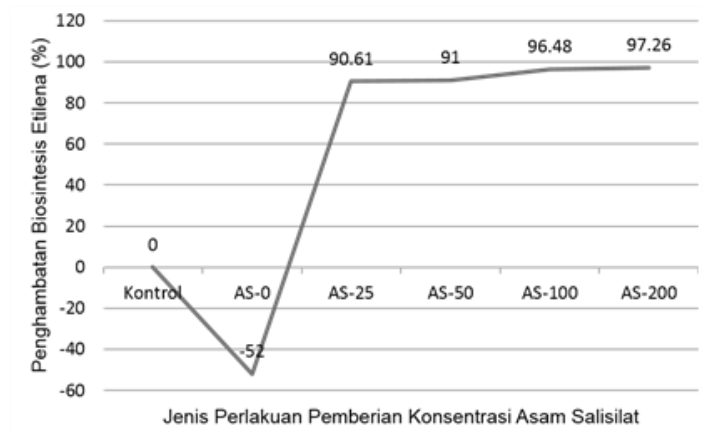

Picture 1. Inhibition Rate of Salicylic Acid against Ethylene Biosynthesis in Apples (Compared to Control)

The effectiveness of using salicylic acid as an inhibitor of ethylene biosynthesis to suppress ethylene concentrations in apple plants can be seen in Figure 1.The results show 
that from the lowest treatment, AS-25 treatment with a salicylic acid concentration of $25 \mathrm{ppm}$ was able to provide an inhibition rate of more than $90 \%$. The effectiveness of AS-25 treatment did not differ much from the result of AS-50 treatment and the effectiveness of AS-100 and AS-200 had similar results with a difference of less than $1 \%$. The highest effectiveness was shown by the treatment of AS-200 with a concentration of $200 \mathrm{ppm}$ of salicylic acid which was able to inhibit ethylene by $97.26 \%$. This shows that the higher the salicylic acid concentration used, the more effective it is in suppressing the ethylene concentration in apple plants.

\section{DISCUSSION}

\section{a. Cost of Making Salicylic Acid from Gandapura Oil}

The raw material is $1 \mathrm{~L}$ gandapura oil then it is fractional distilled. This process was carried out to isolate the methyl salicylate in gandapura oil and the pure methyl salicylate yield was $930 \mathrm{~mL}$ or $1,091.82 \mathrm{~g}$. The methyl salicylate that has been obtained is then synthesized into salicylic acid. The synthesis result was $929.61 \mathrm{~g}$ of salicylic acid with an efficiency of $93.70 \%$.

Table 4. Calculation of Total Production Costs

\begin{tabular}{lll}
\hline No. & Type of Fee & Total Cost (Rp) \\
\hline $\mathbf{1}$ & Fixed cost & \\
& $\begin{array}{l}\text { Rent laboratories and } \\
\text { equipment }\end{array}$ & \\
\hline $\mathbf{2}$ & Variable costs & \\
& Direct labor costs & \\
& & 50,000 \\
& Gandapura oil & 65,000 \\
& $\mathrm{NaOH}$ & 105,000 \\
& $\mathrm{H} 2 \mathrm{SO} 4$ & 120,000 \\
\hline Total & & 540,000 \\
\hline
\end{tabular}

$$
\begin{aligned}
\text { COGS } & =\frac{\text { Total biaya produksi }}{\text { Jumlah produkyang dihasilkan }} \\
& =\frac{\text { Rp } 540.000}{929,61 \mathrm{~g}}
\end{aligned}
$$

$$
=\text { IDR } 581 / \text { gram }
$$

From the calculation of the total production cost, it is known that to get 929.61g of salicylic acid, it requires a cost of Rp.540,000, where the cost of production of salicylic acid is Rp.581 / gram.

\section{b. Comparison of Apple Production Costs with Salicylic Acid and Import Promoter}

Every period of apple production for a 1 hectare plantation area requires two sprays (at the beginning after planting and at the time of flowering). From the research results it is known that the optimum results were obtained in the treatment of 200ppm salicylic acid. For $1 \mathrm{Ha}$, it takes 4,000 L of 200ppm (mg / $\mathrm{L})$ solution of salicylic acid. Then the quantity of salicylic acid capacity needed is: $200 \mathrm{mg} / \mathrm{L} \times$ $4000 \mathrm{~L}=800,000 \mathrm{mg}=800 \mathrm{~g}$. Therefore, $1,600 \mathrm{~g}$ of salicylic acid is needed in one harvest period. For the use of imported promoters, in one harvest period on 1 hectare of land, 8 bottles or about $2 \mathrm{~L}$ are needed. The comparison of the costs that must be spent with these two ingredients can be seen in Table 5. From Table 5 it is known that using salicylic acid farmers can save costs of Rp. 3,070.

Table 5. Comparison of Salicylic Acid Price with Import Promoter

\begin{tabular}{lll}
\hline Parameter & $\begin{array}{l}\text { Salicylic } \\
\text { acid }\end{array}$ & Import Promoter \\
\hline Price & Rp581/g & $\begin{array}{l}\text { IDR 500,000 / } \\
250 \mathrm{ll}\end{array}$ \\
\hline $\begin{array}{l}\text { Requirement } \\
\text { Ha }\end{array}$ & 8009 & $1 \mathrm{~L}$ \\
\hline $\begin{array}{l}\text { Cost/Ha } \\
\text { Rp464,80 }\end{array}$ & IDR 2,000,000 \\
\hline $\begin{array}{l}\text { One-time cost } \\
\text { of harvest }\end{array}$ & Rp929,600 & IDR 4,000,000 \\
\hline $\begin{array}{l}\text { Difference in cost per one } \\
\text { harvest period }\end{array}$ & Rp3,070,400 \\
\hline
\end{tabular}

Apple production costs are the total costs used in one harvest or half a year. Production costs consist of fixed costs and variable costs / variable costs. Variable costs include the cost of procuring fertilizers, pesticides, utilities, labor costs and 
growth regulators (ZPT) which can be in the form of imported promoters or can be replaced by the use of salicylic acid. Comparison of the cost of producing apples using imported promoters and salicylic acid in one harvest period in an area of $1 \mathrm{Ha}$ can be seen in Table 6 .

Table 6. Comparison of Estimated Production Costs of Apples / Season / Ha with Import Promoters and with Salicylic Acid

\begin{tabular}{|c|c|c|c|c|c|}
\hline \multirow{2}{*}{ No. } & \multirow{2}{*}{ Description } & \multicolumn{2}{|l|}{ Cost (Rp) } & \multicolumn{2}{|c|}{ Percentage (\%) } \\
\hline & & A & B & A & B \\
\hline \multirow[t]{2}{*}{1} & Fixed cost & & & & \\
\hline & Rent land & $10,000,000$ & $10,000,000$ & 19.80 & 36.46 \\
\hline \multirow[t]{8}{*}{2} & Variable costs & & & & \\
\hline & a. Utilities & $1,500,000$ & $1,500,000$ & 2.97 & 5.47 \\
\hline & b. Organic fertilizer & $5,000,000$ & $5,000,000$ & $9 \cdot 90$ & 18.22 \\
\hline & c. Inorganic fertilizers & $2,000,000$ & & 3.96 & \\
\hline & d. Pesticide & $13,000,000$ & & 25.75 & \\
\hline & e. Promoter import / Salicylic Acid & $4,000,000$ & 929,600 & 7.92 & $3 \cdot 39$ \\
\hline & f. Maintenance and harvesting labor & $15,000,000$ & $10,000,000$ & 29.70 & 36.46 \\
\hline & Total variable costs & $40,500,000$ & $17,429,600$ & 80.20 & 63.54 \\
\hline \multicolumn{2}{|c|}{ Total Production Costs } & $50,500,000$ & $27,429,600$ & 100 & 100 \\
\hline
\end{tabular}

* A: Production costs using the import promoter; B: Production costs using salicylic acid

From Table 6, it can be seen that the cost of producing apples using the import promoter per season is IDR 50,500,000 and the cost of producing apples using salicylic acid as a growth regulator (ZPT) per season is IDR $27,429,600$. If observed, the percentage of costs used for the two growth regulators (ZPT) used was quite different, $7.92 \%$ for the use of imported ZPT promoter and 3.39\% of the total production costs for the use of salicylic acid ZPT. This figure can indicate that the use of salicylic acid ZPT is more efficient for the overall cost of apple production. In apple production that uses salicylic acid, does not use inorganic fertilizers and pesticides because salicylic acid can increase plant immunity against pathogens (An \& Mou, 2011), and salicylic acid in particular is also able to influence the process of seed germination, seed formation, cell growth, respiration, stomatal closure, aging-related gene expression, abiotic pressure response, basal thermotolerance, legume nodulation and fruit yield (Vlot et al., 2009). The absence of the use of inorganic fertilizers makes some employees work less, so that the labor costs are less.

\section{CONCLUSION}

The best results were obtained in the treatment of $200 \mathrm{ppm}$ salicylic acid concentration. This is shown by the $200 \mathrm{ppm}$ concentration treatment which produced the most fruit with a larger size than other treatments, and the lowest ethylene concentration was produced. The use of salicylic acid alternatives can benefit farmers. In one harvest period, the percentage of costs incurred for salicylic acid is $3.39 \%$ of the total production cost, while the cost of the import promoter is $7.92 \%$ of the total production cost.

\section{REFERENCES}

An, C., \& Mou, Z. (2011). Salicylic Acid and its Function in Plant ImmunityF: Defense Signal Molecule Salicylic Acid. Journal of Integrative Plant Biology, 53(6), 412428. $\quad$ https://doi.org/10.1111/j.17447909.2011.01043.x

Asghari, M., \& Aghdam, M. S. (2010). Impact of salicylic acid on post-harvest physiology of horticultural crops. Trends in Food Science \& Technology, 21(10), 502-509. https://doi.org/10.1016/j.tifs.2010.07.00 9

Djamhari, S. (2010). (Curcuma xanthorrhiza ROXB) MENGGUNAKAN. 12(1), 5.

Ferretti, G., Turco, I., \& Bacchetti, T. (2014). Apple as a Source of Dietary Phytonutrients: Bioavailability and 
Evidence of Protective Effects against Human Cardiovascular Disease. Food and Nutrition Sciences, 05(13), 12341246.

https://doi.org/10.4236/fns.2014.513134

Gardjito, M., Handayani, widuri, \& Salfarino, R. (2015). Penanganan segar hortikultura untuk penyimpanan dan pemasaran. PRENADAMEDIA GROUP.

Leslie, C. A., \& Romani, R. J. (1986). Salicylic acid: A new inhibitor of ethylene biosynthesis. Plant Cell Reports, 5(2), 144-146. https://doi.org/10.1007/BFo0269255

Leslie, C. A., \& Romani, R. J. (1988). Inhibition of Ethylene Biosynthesis by Salicylic Acid. Plant Physiology, 88(3), 833-837. https://doi.org/10.1104/pp.88.3.833

Moore, T. C. (1979). Auxins. In: Biochemistry and Physiology of Plant Hormones. In Auxin and Plant Growth. Springer.

Ruminta. (2015). Dampak perubahan iklim pada produksi apel di Batu Malang Impacts of climate change on production of apple in Batu Malang. Jurnal Kultivasi, 14(2).

Vlot, A. C., Dempsey, D. A., \& Klessig, D. F. (2009). Salicylic Acid, a Multifaceted Hormone to Combat Disease. Annual Review of Phytopathology, 47(1), 177206.

https://doi.org/10.1146/annurev.phyto.o 50908.135202

Würschum, T., Tucker, M. R., Maurer, H. P., \& Leiser, W. L. (2015). Ethylene inhibitors improve efficiency of microspore embryogenesis in hexaploid triticale. Plant Cell, Tissue and Organ Culture (PCTOC), 122(3), 751-757. https://doi.org/10.1007/s11240-0150808-1

Yulianti, S., Irlansyah, \& Junaedi, E. (2007). Khasiat \& Manfaat Apel. AgroMedia Pustaka. 